Marks and his staff at the Group Laboratories, Epsom Hospital, for the insulin result;, control values, and much help and encouragement; and Dr. J. H. Margerison and Mrs. P. Levi for taking and interpreting the electroencephalograms. Help with the statistics was given by Mr. M. Curwen at Guy's Hospital, and the manuscript could not have been drawn up without the unfailing help of Miss E. Arthur, of St. Albans City Hospital. Finally, many nurses and students helped to collect the data and all are gratefully acknowledged.

\section{References}

Bickel, G., Mozel, J. J., and Jaundry, R. (1935). Bulletins et Mémoires de la Socièté des IIopitaux de Paris, 51, 12.

Bielchowski, F. (1932). Klinische W'ochenschrift, 11, 1491.

Breidahl, H. D., Priestley, J. T., and Rynearson, E. H. (1955). Annals of Surgery, 142, 693 .

Cattell, R. B., and Warren, K. W. (1953). Surgery of the Pancreas. Philadelphia, Saunders.

Conn, J. W. (1946). Proceedings of the Diabctes Association, 5, 79.

Courville, C. B. (1957). Archives of Neurology and Psychiatry, 78, 1.

Etheridge, J. E., and Millichap, J. G. (1964). Neurology (Minneapolis), 14, 397.
Gittler, R. D., Zucker, G., Eisenger, R., and Stolter, N. (1958). New England fournal of Medicine, 258, 932.

Hales, C. M., and Randle, P. J. (1963). Lancet, 1, 200

Ingram, T. T. S., Stark, G. D., and Blackburn, Ivy. (1967). Brain, 90, 851. Izzo, J. L., Schuster, D. B., and Engle, L. E. (1953). Diabetes, 9, 93.

Jones, G. M. (1947). American Fournal of the Medical Sciences, 213, 206.

Klinik, D. D., Zalme, E., and Knowles, H. C. (1967). Archives of Internal Medicine, 119, 211.

Knight, P. O. (1967). Southern Medical fournal, 60, 119.

Laroche, G. P., Ferris, D. O., Priestley, J. T., Scholz, D. A., and Dockerty, M. B. (1968). Archives of Surgery, 96, 763 .

Like, A. A., Steinke, J., Jones, E. E., and Cahill, G. F. (1965). American Fournal of Pathology, 46, 621.

Markowitz, A. M., Slanetz, C. A., and Frantz, Virginia K. (1961). Annals of Surgery, 154, 877.

Marshall, S. F. (1958). Surgical Clinics of North America, 38, 743.

Mengoli, L., and Le Quesne, L. P. (1967). British fournal of Surgery, 54, 749 .

Moss, N. H., and Rhoads, J. E. (1960). Surgical Diseases of the Pancreas, ed. J. M. Howard, and G. L. Jordan, p. 321 . London, Pitman.

Priestley, J. T. (1962). Annals of the Royal College of Surgeons of England, 31, 211.

Remine, W. H., Scholz, D. A., and Priestley, J. T. (1960). American fournal of Surgery, 99, 413 .

Schumacker, H. B. (1940). Annals of Surgery, 112, 177

Schumacker, H. B. (1940). Annals of Surgery, 112, 177.
Søgaard, O. L., and Aargard, P. (1968). Danish Medical Bulletin, 14, 1.

Soper, R. T., Koch, T. H., Gius, J. A., and Liechty, R. D. (1968). Fournal of the Iowa Medical Society, 58, 579.

Van Der Sar, A., Bosschieter, E., Hugenholtz, M. J., and Van Der Hoeven, L. (1956). Documenta de Medicina Geographica et Tropica, 8, 85.

\title{
Paracetamol and Renal Damage
}

\author{
O. M. EDWARDS, PAULINE EDWARDS， E. C. HUSKISSON， R. T. TAYLOR
}

British Medical fournal, 1971, 2, 87-89

\section{Summary}

Renal function was assessed in 18 patients who had consumed 2 to $30 \mathrm{~kg}$ of paracetamol. No relationship was found between the total amount of paracetamol taken and any aspect of renal function studied. No pa:ient had clinically significant renal impairment. Thirteen of the patients showed no significant deterioration of renal function over a period of about one year during which they consumed an additional mean $2 \mathrm{~kg}$ of paracetamol.

\section{Introduction}

In recent years it has become clear that renal damage may be caused by consuming large amounts of analgesic mixtures. Because most of the affected patients have taken preparations containing phenacetin, this substance has been particularly implicated. Suspicion has also fallen on paracetamol, because it is a metabolic product of phenacetin. Two cases of nephropathy associated with paracetamol consumption have been reported (Krikler, 1967; Kerr, 1970). Kincaid-Smith (1969) noted that patients with analgesic nephropathy, which she attributed to phenacetin, failed to improve as expected

\section{Westminster Hospital, London, S.W.1}

O. M. EDWARDS, M.B., M.R.C.P., Research Registrar, Metabolic Unit PAULINE EDWARDS, M.в., Research Registrar, Metabolic Unit

E. C. HUSKISSON, M.B., M.R.C.P., Research Registrar, Rheumatology Department

R. T. TAYLOR, M.B., M.R.C.P., Senior Registrar when analgesic treatment was continued with paracetamol and aspirin in combination. On the basis of this evidence Koutsaimanis and de Wardener (1970) suggested that the use of paracetamol should be restricted by making it available only on prescription.

Paracetamol is widely used, low toxicity and absence of gastric irritation making it particularly suitable for patients with rheumatic diseases. A number of patients attending the rheumatism clinic at Westminster Hospital have consumed large amounts of paracetamol regularly; renal function has been studied in these patients to determine whether or not there is evidence of renal damage resulting from prolonged ingestion of paracetamol.

\section{Patients and Methods}

The 18 patients studied had all consumed at least $1 \mathrm{~g}$ of paracetamol daily for at least a year. Total drug consumption was determined from the patient's history with the aid of prescribing records. Schirmer's (1903) test of lachrymal secretion was performed, a value of less than $5 \mathrm{~mm}$ being taken as positive and indicative of Sjögren's syndrome.

During admission to hospital for 36 hours three blood samples were taken for estimation of urea and the mean value was calculated. Haemoglobin and bicarbonate levels were measured on the first sample. Two midstream specimens of urine were collected and cultured for organisms; the centrifuged deposit was examined for white cells and casts. Urine was collected during the first 24 hours for measurement of protein and creatinine excretion. During the first six hours a urinary acidification test was performed. Gelatin-coated ammonium chloride capsules $(0.1 \mathrm{~g} / \mathrm{kg}$ body weight) were given with water during the first hour, and $\mathrm{pH}$, total acidity, titratable acidity, and ammonium excretion were determined in the urine sample collected between the fourth and sixth 
hours (Edwards et al., 1964). Serum and urinary creatinine levels were measured by the method of Wootton (1964). On the second day a urine concentration test was carried out. Pitressin tannate 5 IU in oil was given by subcutaneous injection. An Advanced osmometer was used to measure the osmolality of urine samples taken two-hourly either for eight hours or until the value exceeded $800 \mathrm{mOsm} / \mathrm{kg}$.

In 13 patients the blood urea, serum creatinine, and creatinine clearance were determined on two occasions separated by a mean interval of 13.3 months.

\section{Results}

Clinical details and total quantities of analgesics consumed are shown in Table I. Results of the renal function tests are shown in Table II. Two patients vomited after taking ammonium chloride and the acidification test was discontinued. In one patient there was insufficient urine to measure ammonium excretion. One patient was found to have pyuria and bacteriuria, two had bacteriuria without pyuria, and in the remaining 15 the midstream specimens of urine were normal.

A correlation was sought between the total amount of paracetamol ingested and creatinine clearance, titratable acidity, and ammonium excretion. The correlation coefficients, $+0.35,+0.30$, and +0.23 respectively, were not statistically significant $(t=1.6,1.2$ and $0.9 ; \mathrm{P}>0.1)$. Twelve of the 18 patients concentrated normally to $800 \mathrm{mOsm} / \mathrm{kg}$ or more; mean paracetamol consumption in these patients was $10.7 \mathrm{~kg}$ compared with $9.3 \mathrm{~kg}$ in those who failed to concentrate normally. Thus no relationship was found between these aspects of renal function and the total amount of paracetamol consumed.

Results in the 13 patients who were investigated twice are shown in Table III, and were analysed by a paircd $t$ test.

TABLE III-Mean Values and Standard Deriations for 13 Paticnts Tcsted Twice at a Mean Interval of 13.3 Months. Results were analysed by a Paircd $\mathrm{t}$ Test; Values of $\mathrm{t}$ and Significant Levels are Shown

\begin{tabular}{|c|c|c|c|c|}
\hline & 1st Test & 2nd Test & $t$ & $\mathrm{P}$ \\
\hline $\begin{array}{l}\text { Paracetamol consumption }(\mathrm{kg}) \\
\text { Urea }(\mathrm{mg} 100 \mathrm{ml}) \\
\text { Creatinine clearance }(\mathrm{ml} / \mathrm{min}) \\
\text { Serum creatinine }(\mathrm{mg} 100 \mathrm{ml})\end{array}$ & 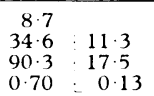 & $\begin{array}{cc}10 \cdot 7 & \\
38 \cdot 0 & 7.5 \\
95.7 & 27 \cdot 8 \\
0.77 & 0.20\end{array}$ & $\begin{array}{l}1.0 \\
0.7 \\
1.4\end{array}$ & $\begin{array}{l}0.1 \\
0.1 \\
0.1\end{array}$ \\
\hline
\end{tabular}

There was no significant deterioration in renal function during a mean period of 13.3 months in which the patients consumcd a mean additional $2 \mathrm{~kg}$ of paracetamol.

\section{Discussion}

Though we cannot positively exclude the existence of analgesic nephropathy in every patient in this series, none had severe impairment of renal function and those tested twice showed no evidence of renal deterioration. None of our patients had sterile pyuria. Impairment of concentrating ability, the commonest functional abnormality in patients with

TABLE I-Clinical Details of Patients studied, with Total Quantities of Drugs Consumcd

\begin{tabular}{|c|c|c|c|c|c|c|c|c|c|c|c|c|c|}
\hline \multirow{2}{*}{ Case No. } & & \multirow{2}{*}{ Age } & \multirow{2}{*}{ Sex } & \multirow{2}{*}{ Diagnosis } & \multirow{2}{*}{$\begin{array}{c}\text { Schirmer } \\
\text { Test }\end{array}$} & \multicolumn{3}{|c|}{ Analgesic (kg) } & \multirow{2}{*}{$\begin{array}{l}\text { Gold } \\
\text { Therapy }\end{array}$} & \multirow{2}{*}{$\begin{array}{l}\text { Past Urinary } \\
\text { Infection }\end{array}$} & \multirow{2}{*}{$\begin{array}{l}\text { Peptic } \\
\text { Ulcer }\end{array}$} & \multicolumn{2}{|c|}{ Blood Pressure } \\
\hline & & & & & & Paracetamol & Phenacetin & Aspirin & & & & Systolic & Diastolic \\
\hline $\begin{array}{r}1 \\
2 \\
3 \\
4 \\
5 \\
6 \\
7 \\
8 \\
9 \\
10 \\
11 \\
12 \\
13 \\
14 \\
15 \\
16 \\
17 \\
18\end{array}$ & 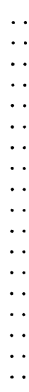 & $\begin{array}{l}69 \\
62 \\
62 \\
64 \\
64 \\
75 \\
61 \\
50 \\
72 \\
52 \\
54 \\
72 \\
48 \\
67 \\
62 \\
70 \\
65 \\
46\end{array}$ & $\begin{array}{l}\text { M. } \\
M . \\
F . \\
F . \\
F . \\
F . \\
F . \\
F . \\
F . \\
F . \\
M . \\
F . \\
M . \\
F . \\
F . \\
M . \\
M . \\
F .\end{array}$ & $\begin{array}{l}\text { RA } \\
\text { RA } \\
\text { AS } \\
\text { RA } \\
\text { RA } \\
\text { OA } \\
\text { RA } \\
\text { RA } \\
\text { PsA } \\
\text { RA } \\
\text { RA } \\
\text { RA } \\
\text { RA } \\
\text { RA } \\
\text { RA } \\
\text { RA } \\
\text { RA } \\
\text { RA }\end{array}$ & $\begin{array}{l} \pm \\
\pm \\
\pm \\
\pm \\
\pm \\
\pm \\
\pm \\
+ \\
\pm \\
\pm \\
+ \\
\pm \\
\end{array}$ & $\begin{array}{r}2 \cdot 7 \\
2 \cdot 8 \\
4 \cdot 3 \\
4 \cdot 4 \\
4.5 \\
5 \cdot 3 \\
6 \cdot 1 \\
6 \cdot 6 \\
7.5 \\
7.7 \\
7.9 \\
10 \cdot 0 \\
10 \cdot 1 \\
11.8 \\
17 \cdot 1 \\
20 \cdot 8 \\
25.5 \\
29 \cdot 6\end{array}$ & $\begin{array}{l}1 \cdot 7 \\
= \\
1 \cdot 8 \\
= \\
= \\
= \\
= \\
= \\
= \\
= \\
=\end{array}$ & $\begin{array}{l}1.7 \\
2.0 \\
2.9 \\
= \\
\overline{-} \\
0.4 \\
1.5 \\
= \\
\overline{-} \\
3.0 \\
\frac{3.6}{\overline{3}} \\
3.5\end{array}$ & 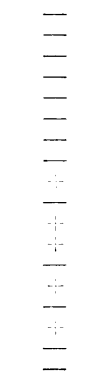 & $\begin{array}{l}= \\
\pm \\
+ \\
= \\
= \\
= \\
+ \\
+ \\
= \\
=\end{array}$ & $\begin{array}{l}-1 \\
= \\
= \\
= \\
= \\
= \\
- \\
= \\
= \\
=\end{array}$ & $\begin{array}{l}160 \\
120 \\
140 \\
170 \\
190 \\
150 \\
180 \\
130 \\
200 \\
140 \\
160 \\
200 \\
130 \\
160 \\
140 \\
120 \\
120 \\
140\end{array}$ & $\begin{array}{r}100 \\
80 \\
80 \\
100 \\
110 \\
90 \\
90 \\
90 \\
100 \\
80 \\
80 \\
140 \\
80 \\
90 \\
90 \\
80 \\
80 \\
90\end{array}$ \\
\hline
\end{tabular}

RA $=$ Rheumatoid arthritis. $\mathrm{OA}=$ Osteoarthritis. PsA $=$ Psoriatic arthropathy. $\mathrm{AS}=$ Ankylosing spondylitis.

TABLE II-Results of Renal Function Tests

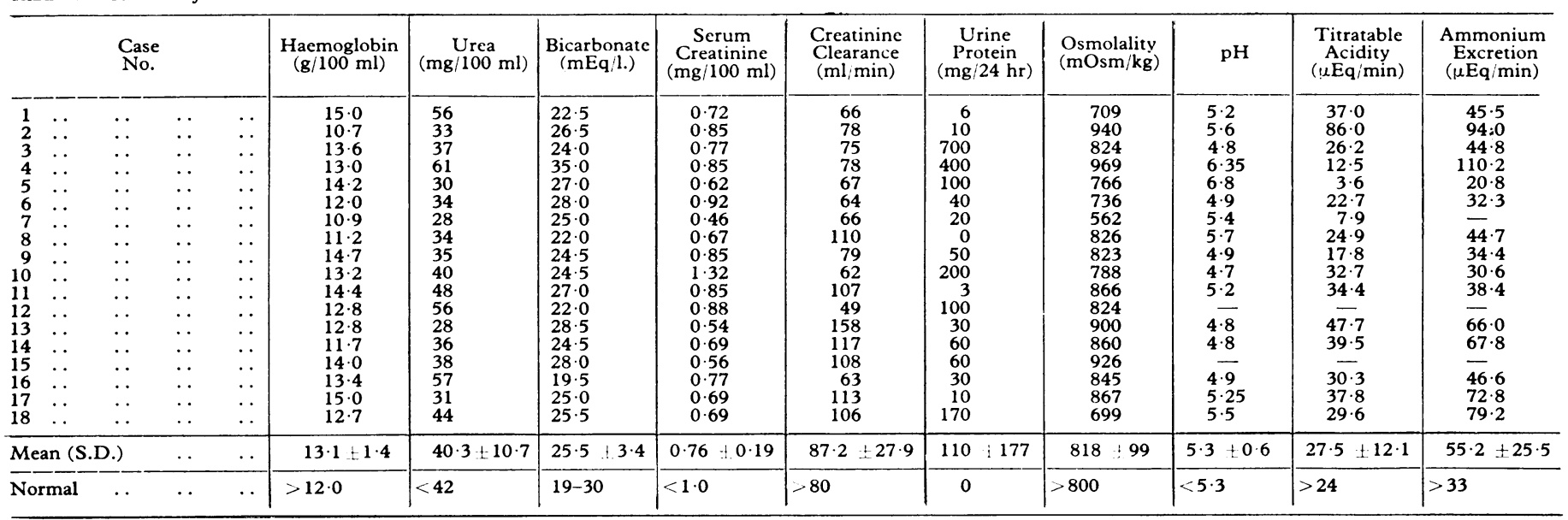


analgesic nephropathy (Steele et al., 1969), was present in six patients but was of minor degree. Neither the incidence nor the severity of this abnormality was related to the total amount of paracetamol consumed.

It is not surprising that some minor renal functional abnormalities were found in our group of elderly patients, most of whom were suffering from rheumatoid arthritis. Burry (1970) showed that impaired glomerular function may be associated with rheumatoid arthritis; he found a creatinine clearance of less than $80 \mathrm{ml} / \mathrm{min}$ in 49 out of 97 unselected patients, and showed a correlation between reduction of glomerular filtration and the presence of radiological articular erosions. Patients with Sjögren's syndrome may also be unable to concentrate or acidify their urine (Kahn et al., 1962; Talal et al., 1968). Eight of our patients had a positive Schirmer's test, and urinary concentration or acidification was abnormal in four.

The evidence implicating paracetamol lies in its chemical relationship to phenacetin, in two reported cases of suspected paracetamol nephropathy, and in its effect on the course of established analgesic nephropathy. Prescott (1970) suggested that phenacetin is not the cause of analgesic nephropathy and claimed that salicylates or mixtures containing salicylates are responsible. Animal work cannot necessarily be extrapolated to man, but supports this concept. Aspirin and mixtures containing aspirin cause papillary necrosis in rats but phenacetin alone does not (Saker and Kincaid-Smith, 1969; Nanra and Kincaid-Smith, 1970). Only two cases of analgesic nephropathy attributable to paracetamol abuse have been reported, despite the widespread use of the drug; it is notoriously difficult to be certain that patients have not consumed other drugs, and this is well illustrated by the first case reported by Kerr (1970). Kincaid-Smith (1969) implicated paracetamol on the basis of its effect on patients with established analgesic nephropathy, but her patients were taking mixtures of paracetamol and salicylates. Our results indicate that paracetamol does not cause significant impairment of renal function, and hence we find no justification to restrict the use of paracetamol by making it available only on prescription.

We wish to thank Dr. F. Dudley Hart and Dr. R. I. S. Bayliss for allowing us to study their patients and for their help and encouragement; Mrs. J. C. Paterson for technical assistance; the department of chemical pathology and haematology for urea, bicarbonate, urine protein, and haemoglobin estimations; the department of bacteriology for examination of midstream specimens of urine; and the patients for their willing co-operation.

\section{References}

Burry, H. C. (1970). Paper presented at a meeting of the Heberden Society Edwards, K. D. G. Stewart, J. H., Ashley, B. C. E., and Whyte, H. M. (1964). Proceedings of the Australian Association of Clinical Biochemists, 1, 101 .

Kahn, M., Merritt, A. D., Wohl, M. J., and Orloff, J. (1962). Annals of Internal Medicine, 56, 883.

Kerr, D. (1970). British Medical fournal, 4, 363.

Kincaid-Smith, P. (1969). Medical fournal of Australia, 2, 1131

Koutsaimanis, K. G., and de Wardener, H. E. (1970). British Medical fournal, 4,131 .

Krikler, D. M. (1967). British Medical fournal, 2, 615.

Nanra, R. S., and Kincaid-Smith, P. (1970). British Medical fournal, 3, 559.

Prescott, L. F. (1970). British Medical fournal, 4, 493.

Saker, B. M., and Kincaid-Smith, P. (1969). British Medical Fournal, 1, 161. Schirmer, O. (1903). Albrecht v. Graefes Archiv für Ophthalmologie, 56, 187. Steele, T. W., Gyory, A. Z., and Edwards, K. D. G. (1969). British Medical fournal, 2,213

Talal, N., Zisman, E., and Schur, P. H. (1968), Arthritis and Rheumatism, 11,774 .

Wootton, I. D. P. (1964). In Micro-Analysis in Medical Biochemistry 4th edn. London, Churchill.

\section{MEDICAL MEMORANDA}

\section{Idiopathic Steatorrhoea and Idiopathic Pulmonary Haemosiderosis}

\author{
D. J. LANE, W. S. HAMILTON
}

British Medical fournal, 1971, 2, 89-90

The aetiology of idiopathic pulmonary haemosiderosis is unknown. In the present case it was seen in association with idiopathic steatorrhoea.

\section{Case Report}

A 23-year-old man had first presented at the age of 9 years with a two-year history of attacks of postprandial epigastric pain Haemoglobin was $8.1 \mathrm{~g} / 100 \mathrm{ml}$ but occult blood was absent and

Nuffield Departments of Medicine and Anaesthetics, Radcliffe Infirmary, Oxford OX2 $6 \mathrm{HE}$

D. J. LANE, D.M., M.R.C.P., Lecturer

Churchill Hospital, Oxford OX3 7LJ

W. S. HAMILTON, B.M., M.R.C.P., Consultant Chest Physician stool faecal fat contents of 3.2 and $3.8 \mathrm{~g} / 24$ hours did not suggest malabsorption. Oral iron was given, raising the haemoglobin to $11.9 \mathrm{~g} / 100 \mathrm{ml}$. At age 12 he was anaemic again (haemoglobin $9.6 \mathrm{~g} / 100 \mathrm{ml}$ ) and was below normal height for his age. Barium studies showed appearances compatible with chronic duodenal ulceration. Tessts for occult blood were still negative. Over the next four years his condition remained chronically unsatisfactory, with features of intermittent abdominal pain, poor appetite, recurrent mouth ulcers, listlessness, lack of growth, and persistent irondeficiency anaemia. Further tests for malabsorption (faecal fat and xylose absorption) at age 13 and 16 were again negative and barium 'studies again suggested a scarred duodenal cap.

When he was aged 18 a febrile respiratory tract illness with severe haemoptysis and changes in both lower lung fields on chest $x$-ray examination led to a provisional diagnosis of idiopathic pulmonary haemosiderosis. A review of previous radiographs suggested that infiltration had been present for 10 years. Examination showed a ismall but well-nourished man who shaved little and had an unbroken voice; his pubic hair and external genitalia were normally developed.

Investigation.-Haemoglobin $6.9 \mathrm{~g} / 100 \mathrm{ml}$; M.C.H.C. $27 \%$; P.C.V. $25 \%$; film, hypochromia with occasional macrocytes; bone marrow, normoblastic haemopoiesis; serum iron $60 \mu \mathrm{g} / 100 \mathrm{ml}$; serum vitamin $B_{1} 245 \mathrm{pg} / \mathrm{ml}$. Iron intake was satisfactory in terms of both food and iron preparations: iron loss seemed unlikely since only one out of 10 stool specimens was positive for occult blood. Faecal fat excretion $7.6 \mathrm{~g} / 24$ hours; prothrombin to $61 \%$ to $72 \%$.

(Owren); total proteins $7 \cdot 1 \mathrm{~g} / 100 \mathrm{ml}$ (albumin $2.5 \mathrm{~g}$ ). Barium studies of the small bowel showed dilatation and flocculation compatible with malabsorption. Jejunal biopsy showed sub-total villous atrophy, establishing a diagnosis of idiopathic steatorrhoea (Fig. 1). Sweat sodium concentration was normal. Iron-laden macrophages were 